\title{
Distal Protection During Primary Percutaneous Coronary Intervention for ST-elevation Myocardial Infarction
}

\author{
Masaharu Ishihara
}

Division of Coronary Artery Disease, Department of Internal Medicine, Hyogo College of Medicine, Hyogo, Japan

\section{See article vol. 23: 1313-1323}

Primary percutaneous coronary intervention (PCI) is the standard treatment strategy for patients with STelevation myocardial infarction (STEMI). However, despite the early restoration of epicardial artery flow, microvascular obstruction and reduced myocardial perfusion may occur. The "no-reflow" phenomenon is associated with a large infarct size and poor outcomes. The pathogenesis of no-reflow phenomenon is multifactorial, which includes distal embolization, ischemiareperfusion injury, and ischemic insult. There have been several attempts to prevent the no-reflow phenomenon. An early reperfusion to shorten the ischemic time is pivotal to attenuate the ischemic insult and prevent no-reflow; however, the role of adjunctive pharmacological intervention, such as human atrial natriuretic peptide, or mechanical intervention, such as remote-/post-conditioning, in preventing the reperfusion injury remains inconclusive.

During PCI, intracoronary thrombus and atherosclerotic plaques are crushed and streamed down the coronary artery. The atherothrombotic debris can be detected as high-intensity transient signals using a Doppler guide wire, immediately after the balloon deflation ${ }^{1}$. No-reflow phenomenon may occur, if the size and number of emboli are large enough to obstruct the coronary microcirculation. A thrombus aspiration device was developed to reduce the thrombus burden that has the potency to become the source of emboli. Thrombus aspiration during PCI in Acute myocardial infarction Study (TAPAS) randomized 1,071 patients with STEMI to aspiration before stent-

Address for correspondence: Masaharu Ishihara, Division of Coronary Artery Disease, Department of Internal Medicine, Hyogo College of Medicine, 1-1, Mukogawa-cho, Nishinomiya, Hyogo 663-8501, Japan

E-mail: ma-ishihara@hyo-med.ac.jp

Received: May 20, 2016

Accepted for publication: May 23, 2016 ing and conventional PCI. It was reported in 2008 that thrombus aspiration improved the myocardial perfusion after PCI and reduced the rate of 1-year cardiac death or re-infarction ${ }^{2)}$. The ACC/AHA 2011 PCI guidelines and 2013 STEMI guidelines recommended thrombus aspiration as belonging to Class $\Pi \mathrm{a}^{3,4)}$. However, in 2015 the Trial of Routine Aspiration Thrombectomy with PCI versus PCI Alone in Patients with STEMI (TOTAL) that randomized patients with 10,732 failed to show any clinical benefits of aspiration thrombectomy and rather showed higher incidences of stroke in the thrombectomy group ${ }^{5)}$. The 2015 STEMI guidelines modified the recommendations for aspiration thrombectomy, i.e., routine aspiration was classified as Class III and selective/bailout aspiration as Class $\Pi \mathrm{b}^{6}$.

Distal protection prevents embolization of atherothrombotic debris during PCI. Filter-based devices are currently used, as they maintain perfusion during the procedure and have shown to be safe and effective in comparison to the balloon occlusion devices. PCI of saphenous vein graft (SVG) carries a significant risk of no-reflow, periprocedural MI, and adverse clinical events as the degenerated SVG lesions contain friable lipid-rich plaques. Saphenous vein graft Angioplasty Free of Emboli Randomized (SAFER) trial demonstrated that the use of distal protection device decreased the risk of PCI in $\mathrm{SVG}^{7}$. The $2011 \mathrm{PCI}$ guidelines recommend the distal (embolic) protection devices as Class I for SVG PCI. However, previous studies failed to show the efficacy of distal protection for native-artery PCI, even in patients with STEMI. Drug Elution and Distal Protection in ST-Elevation Myocardial Infarction (DEDICATION) trial randomly assigned 626 patients with STEMI to have PCI with or without distal protection. There was no difference in ST resolution, troponin/CK-MB levels, and left ventricular wall motion index ${ }^{8)}$. Moreover, there was a higher tendency toward re-MI and target lesion revascularization in patients with distal protection. Currently, routine use of distal protection has not been rec- 
ommended for patients with STEMI undergoing PCI.

In this issue of the journal, Teramoto et al. reviewed 164 patients with acute MI (mostly STEMI) who had undergone PCI and investigated the efficacy of distal protection ${ }^{9)}$. They reported that the use of filter-based distal protection devices did not affect the incidences of complete ST resolution and peak CK; however, it was associated with lower incidences of heart failure (HF) during a 2-year follow-up. In previous studies, including DEDICATION trial, HF was not assessed. Although the underlying mechanism for this finding remains unclear, distal protection may be useful for some selected patients. The current study was not randomized, and the use of distal protection depended on the physician's decision. Distal protection device might have been used for patients who were more likely expected to receive the benefits. Previous studies using intracoronary imaging modalities, including intravascular ultrasound (IVUS), optical coherence tomography, and coronary angioscopy, have shown the lesion characteristics that are associated with no-reflow after PCI and hence may benefit from distal protection ${ }^{10)}$. Although Teramoto et al. performed quantitative analysis of cross-sectional images of IVUS, longitudinal or qualitative analyses were not performed. Further studies need to be performed in order to clarify the clinical usefulness of distal protection in patients with STEMI undergoing PCI.

\section{References}

1) Okamura $A$, Ito $H$, Iwakura $K$, Kawano $S$, Inoue $K$, Maekawa Y, Ogihara T, Fujii K. Detection of embolic particles with the Doppler guide wire during coronary intervention in patients with acute myocardial infarction: efficacy of distal protection device. J Am Coll Cardiol 2005; 45: 212-215

2) Svilaas T, Vlaar PJ, van der Horst IC, Diercks GF, de Smet BJ, van den Heuvel AF, Anthonio RL, Jessurun GA, Tan ES, Suurmeijer AJ, Zijlstra F. Thrombus aspiration during primary percutaneous coronary intervention. $\mathrm{N}$ Engl J Med 2008; 358: 557-567

3) Levine GN, Bates ER, Blankenship JC, Bailey SR, Bittl JA, Cercek B, Chambers CE, Ellis SG, Guyton RA, Hollenberg SM, Khot UN, Lange RA, Mauri L, Mehran R, Moussa ID, Mukherjee D, Nallamothu BK, Ting HH. 2011 ACCF/AHA/SCAI Guideline for Percutaneous Coronary Intervention. A report of the American College of Cardiology Foundation/American Heart Association Task Force on Practice Guidelines and the Society for Cardiovascular Angiography and Interventions. J Am Coll Cardiol 2011; 58: e44-e122

4) O'Gara PT, Kushner FG, Ascheim DD, Casey DE Jr, Chung MK, de Lemos JA, Ettinger SM, Fang JC, Fesmire FM, Franklin BA, Granger CB, Krumholz HM, Linderbaum JA, Morrow DA, Newby LK, Ornato JP, Ou N, Radford MJ, Tamis-Holland JE, Tommaso CL, Tracy CM, Woo YJ, Zhao DX. 2013 ACCF/AHA guideline for the management of ST-elevation myocardial infarction: a report of the American College of Cardiology Foundation/American Heart Association Task Force on Practice Guidelines. J Am Coll Cardiol 2013; 61 : e78-e140

5) Jolly SS, Cairns JA, Yusuf S, Meeks B, Pogue J, Rokoss MJ, Kedev S, Thabane L, Stankovic G, Moreno R, Gershlick A, Chowdhary S, Lavi S, Niemelä K, Steg PG, Bernat I, Xu Y, Cantor WJ, Overgaard CB, Naber CK, Cheema AN, Welsh RC, Bertrand OF, Avezum A, Bhindi R, Pancholy S, Rao SV, Natarajan MK, ten Berg JM, Shestakovska O, Gao P, Widimsky P, Džavík V; TOTAL Investigators. Randomized trial of primary PCI with or without routine manual thrombectomy. N Engl J Med 2015; 372: 1389-1398

6) Levine GN, O'Gara PT, Bates ER, Blankenship JC, Kushner FG, Ascheim DD, Bailey SR, Bittl JA, Brindis RG, Casey DE Jr, Cercek B, Chambers CE, Chung MK, de Lemos JA, Diercks DB, Ellis SG, Fang JC, Franklin BA, Granger CB, Guyton RA, Hollenberg SM, Khot UN, Krumholz HM, Lange RA, Linderbaum JA, Mauri L, Mehran R, Morrow DA, Moussa ID, Mukherjee D, Newby LK, Ornato JP, Ou N, Radford MJ, Tamis-Holland JE, Ting HH, Tommaso CL, Tracy CM, Woo YJ, Zhao DX. 2015 ACC/AHA/SCAI focused update on primary percutaneous coronary intervention for patients with ST-elevation myocardial infarction: an update of the 2011 ACCF/AHA/SCAI guideline for percutaneous coronary intervention and the 2013 ACCF/AHA guideline for the management of ST-elevation myocardial infarction: a report of the American College of Cardiology/American Heart Association Task Force on Clinical Practice Guidelines and the Society for Cardiovascular Angiography and Interventions. J Am Coll Cardiol 2016; 67: 1235-1250

7) Baim DS, Wahr D, George B, Leon MB, Greenberg J, Cutlip DE, Kaya U, Popma JJ, Ho KK, Kuntz RE; Saphenous vein graft Angioplasty Free of Emboli Randomized (SAFER) Trial Investigators. Randomized trial of a distal embolic protection device during percutaneous intervention of saphenous vein aorto-coronary bypass grafts. Circulation 2002; 105: 1285-1290

8) Kelbaek H, Terkelsen CJ, Helqvist S, Lassen JF, Clemmensen P, Kløvgaard L, Kaltoft A, Engstrøm T, Bøtker HE, Saunamäki K, Krusell LR, Jørgensen E, Hansen HH, Christiansen EH, Ravkilde J, Køber L, Kofoed KF, Thuesen L. Randomized comparison of distal protection versus conventional treatment in primary percutaneous coronary intervention: the drug elution and distal protection in STelevation myocardial infarction (DEDICATION) trial. J Am Coll Cardiol 2008; 51: 899-905

9) Teramoto R, Sakata K, Miwa K, Matsubara T, Yasuda T, Inoue $\mathrm{M}$, Okada $\mathrm{H}$, Kanaya $\mathrm{H}$, Wawashiri M, Yamagishi M, Hayashi K. Impact of distal protection with filter-type device on long-term outcome after percutaneous coronary intervention for acute myocardial infarction: clinical results with Filtrap. J Atheroscler Thromb 2016; 23: 1313-1323

10) Ikenaga $H$, Ishihara $M$, Inoue I, Kawagoe $T$, Shimatani $Y$, Miura F, Nakama Y, Dai K, Ohtani T, Ohi K, Miki T, Nakamura M, Kishimoto S, Sumimoto Y, Kihara Y. Longitudinal extent of lipid pool assessed by optical coherence tomography predicts microvascular no-reflow after primary percutaneous coronary intervention for ST-segment elevation myocardial infarction. J Cardiol 2013; 62: 71-76 